\title{
Trade Liberalization and Foreign Direct Investment in Malaysia
}

\author{
Sabariah Nordin, Mohammed B. Yusoff, Gairuzazmi B. Mat Ghani \\ Universiti Utara Malaysia, Malaysia \\ International Islamic University Malaysia \\ norsabariah@uum.edu.my
}

\begin{abstract}
A decision to establish foreign direct investment (FDI) involves a lot of critical thinking, especially in deciding a place to locate the investment. Evaluation and consideration comprise of costs and benefits of launching the FDI. This study focuses on time series data for the sample period of 1970 to 2009. The main objective of this study is to identify the major determinant of the inward flows of FDI for Malaysia by employing the bounds testing (ARDL) approach to cointegration. Of all the variables being tested, trade openness is found to be the most influential variable in attracting the inflows of FDI as it shows consistent results in the short run as well as in the long run in all models being tested. Since the trade openness which represents the liberalization of the Malaysian economy could induce the inflows of FDI, some policy actions can be taken up to enhance the trade openness.
\end{abstract}

Keywords: Trade openness, foreign direct investment, bounds test, cointegration, Malaysia

\section{Introduction}

A decision to establish foreign direct investment (FDI) involves a lot of critical evaluation. Many studies have attempted to examine the conditions that make a country an attractive location to FDI (Ang, 2008; Kang \& Lee, 2007; Cassidy \& Andreosso-0'Callaghan, 2006; Moosa \& Cardak, 2006; Bevan \& Estrin, 2004). GDP of the host country, trade openness, exchange rate, infrastructure development and the cost of labor are among the prominent determinants explored by most studies. Even though there are ample studies on FDI, their results are not conclusive. This is due to the differences in the characteristics of the country of study such as political stability and economic stability, the status of the country being studied, types of data employed, motives of FDI and also the period of study. Even the methodology adopted has a tendency to influence the results. Hence, a continuous study is obviously needed to assess the determinants of FDI. In assessing the determinants of the inward flows of FDI for Malaysia, this study will test a number of factors that could influence the decision to locate FDI in Malaysia. This study is organized as follows: The first section is the introduction. The second section discusses past studies reflecting the variables commonly used to assess the determinants of FDI. The third section explains the methodology, sources of data and definition of variables. The fourth section explains the methods of estimation. The fifth section discusses the results, and finally, the last section concludes the study.

\section{Literature Review}

Since 1970s, numerous studies have been done to examine the factors that attract foreign direct investment into a host country. These studies are important in a way that they help countries to develop policies and enhance facilities that can attract multinational enterprises (MNEs). The findings tend to suggest that the factors that determine FDI of different countries are quite depending on the types of FDI (Fedderke \& Romm, 2006) and the country of study (Ismail \& Yussof, 2003; Asiedu, 2002). Below are empirical discussions on the variables that are tested in this study. This current study focuses on: GDP, Growth rates of GDP, Trade Openness, Exchange Rates, Inflation, and Financial Deepening.

Gross Domestic Product (GDP): Lim (2001), based on a World Bank survey conducted on 173 Japanese firms investing in East Asian countries in 1994, indicates that the most robust determinant for the determinants of FDI is the market size, proxied by real GDP or GDP per capita. Among the studies that 
highlight the significant and positive influence of GDP on FDI include Ang (2008), Cassidy and AndreossoO'Callagahan (2006), Moosa and Cardak (2006), Fedderke and Romm (2006), Gao (2005), Li and Liu (2005), Bevan and Estrin (2004) and Bende-Nabende (2002).On the other hand, Aw and Tang (2010) reveal that the GDP per capita is not significant in the long run, but positive and significant in the short run. Cuyvers, Joseph, Soeng and Bulcke (2008), in determining factors that influence the inflows of FDI for Cambodia indicate that the relative GDP as indicated by the ratio of the host country's GDP to the home country's GDP is not significant in determining annual inflows of real FDI for Cambodia. Meanwhile, Ismail and Yussof (2003) discover that GDP is only significant and positive for Malaysia and Philippines, but not for Thailand.

Growth Rates of GDP: A number of studies manage to reveal the significant and positive influence of the growth rate of GDP on FDI (Shahrudin, Yusof \& Satar, 2010; Demirhan \& Masca, 2008; Li \& Liu, 2005; BendeNabende, 2002; Noorbakhsh, Paloni \& Youssef, 2001). On the other hand, Cuyvers, Joseph, Soeng and Bulcke (2008), the relative GDP growth rate is not significant in determining the approved FDI. Similar to Cuyvers, Joseph, Soeng and Bulcke (2008), Moosa and Cardak (2006) also indicate that the growth rate of GDP is not significant in influencing FDI.

Trade Openness: Lim (2001) indicates that the significance of trade openness in influencing the inflows of FDI are mixed; however, many studies show positive correlation and the significance positive influence of trade openness on FDI (Aw \& Tang, 2010; Yol \& Teng, 2009; Demirhan \& Masca, 2008; Read, 2007; Kang \& Lee, 2007; Moosa \& Cardak, 2006; Li \& Liu, 2005; Bevan \& Estrin, 2004; Noorbakhsh, Paloni \& Youssef, 2001). A study done by Ismail and Yussof (2003) indicates that the trade openness is positive and significant for Thailand, but not for Philippines. Bende-Nabende (2002) finds trade openness as the least significant determinant of FDI. Asiedu (2002) finds that the trade openness is positive and significant, however, the effect of trade openness for the sub-Saharan Africa countries seems to be lesser compared to the non-SSA countries.

Exchange Rates: Studies by Almsafir, Latif and Bekhet (2011) and Cuyvers, Joseph, Soeng and Bulcke (2008) discover a positive significant relationship between FDI and exchange rates. Similarly, Yol and Teng (2009) discover that the real depreciation of ringgit causes FDI to increase in the long run as well as in the short run. On the other hand, a study conducted by Aw and Tang (2010) reveals that the exchange rate of RM/USD is negative and significant in the long run, but positive and significant in the short run. Ang (2008) finds that the real exchange rate is significantly and negatively related to FDI. A study by Kiyota and Urata (2004) indicates that the depreciation of the host country currency attracts FDI and large volatility in real exchange rate restricts FDI. On the other hand, Solocha, Soskin, and Kasoff (1989) find that FDI is positively correlated with the level and volatility of foreign exchange rates.

Inflation: Demirhan and Masca (2008) and Li and Liu (2005) find that the effect of inflation on FDI is negative and significant. However, results by $\mathrm{Li}$ and Liu (2005) further highlight that for developing countries; the coefficient of the inflation variable shows negative and significant result, and for the developed countries, the inflation variable becomes insignificant.

Financial Deepening: Almsafir, Latif and Bekhet (2011) further strengthen the positive relationship that exists between FDI and money supply. Shahrudin, Yusof and Satar (2010) find that money supply of M2 is a significant determinant of FDI in the long run and the short run. Ang (2008) indicates that higher financial development increases FDI inflows.

China Factor: Aw and Tang (2010) reveals that the China's accession into the World Trade Organization (WTO) has a positive long run impact on the inward flows of FDI. On the contrary, Cuyvers, Joseph, Soeng and Bulcke (2008) discover that the China's accession into the WTO negatively affects the flows of FDI.

Other Factors: Ang (2008) finds no significant relationship between Asian financial crisis and the inflows of FDI. Bevan and Estrin (2004) indicate that the announcement of the EU membership has a positive and significant influence on FDI. 


\section{Methodology}

Based on the review of literature, we specify a general model of the determinants of FDI inflows to the host country, Malaysia. We shall call this as Model 1:

$\underline{\text { Model } 1}$

LOGFDI $_{\mathrm{t}}=\beta_{0}+\beta_{1}$ LOGRGDP $_{\mathrm{t}}+\beta_{2}$ LOGOPEN $_{\mathrm{t}}+\beta_{3}$ LOGEXR $_{\mathrm{t}}+\beta_{4}$ TGRO $_{\mathrm{t}}+\beta_{5}$ INGRO $_{\mathrm{t}}+\beta_{6}$ PGRO $_{\mathrm{t}}+\beta_{7} \mathrm{D}_{\mathrm{t}}+$ $\varepsilon_{t} \quad(1)$

Where

$\begin{array}{lll}\text { FDI } & = & \text { foreign direct investment (measured in current RM) } \\ \text { RGDP } & = & \text { real gross domestic product (measured in current RM) } \\ \text { OPEN } & = & \text { ratio of the sum of exports and imports over GDP } \\ \text { EXR } & = & \text { period average official exchange rate (measured as RM/USD) } \\ \text { TGRO } & = & \text { Growth rate of GDP for Thailand } \\ \text { INGRO } & = & \text { Growth rate of GDP for Indonesia } \\ \text { PGRO } & = & \text { Growth rate of GDP for Philippines } \\ \mathrm{D} & = & \text { dummy variable of the accession of China into WTO } \\ \beta_{\mathrm{i}} & = & \text { parameters to be estimated, i }=0,1,2 \ldots \ldots . ., 7 \\ \varepsilon & = & \text { white noise error term. } \\ \mathrm{LOG} & = & \text { logarithm } \\ \mathrm{t} & = & \text { time }\end{array}$

Additional variables which will be considered in other models to test the robustness of variables identified in equation (1):

$\begin{array}{lll}\text { M2 } & = & \text { financial deepening (money supply of M2) } \\ \text { INFL } & = & \text { inflation rate } \\ \text { GDPG } & = & \text { Malaysian Growth rate of GDP }\end{array}$

Many studies have included the size of the host country's market as one of the explanatory variables proxied by gross domestic product (GDP) of the host country (Ang, 2008; Cassidy \& Andreosso-0'Callaghan, 2006; Moosa \& Cardak, 2006; Bevan \& Estrin, 2004; Ismail \& Yussof, 2003; Bende-Nabende, 2002). The market-size hypothesis is an important determinant for a vertical type of FDI. Another popularly used explanatory variable is the trade openness. According to Hasan (2004), one of the reasons for the important role played by FDI in Malaysia is the preference of the multinational corporations to establish and finance industries geared towards exports. Even since 1971 Malaysia is known to be an export-oriented economy, and highly depends on foreign investors (Bjorvatn, Kind \& Nordås, 2001). By focusing on the roles performed by GDP and trade openness in attracting FDI, the two seem to benefit MNEs in boosting their sales. Since an MNE is a foreign enterprise involves in international transactions, involvement with the foreign exchange market is unavoidable. Furthermore, the physical establishment of the FDI itself engages with the foreign exchange market. Past empirical studies have been showing mixed results on the significance and signs of the exchange rates.

Another variable that has recently received considerable attention is the financial deepening of the host country which measures the depth of a country's financial development. Financial development is considered an important variable because the advancement of the financial landscape of the host country mirrors the availability and easiness of getting funds. Even though foreign investors do not depend on domestic sources of capital, the easiness of doing transactions, and the efficient services provided by financial institutions in the host country attract the attention of foreign investors to invest there. In measuring the depth of the Malaysian financial landscape, this study employs the money supply of M2. A higher degree of financial development is expected to increase the inward flows of FDI. Inflation, a rise in the general level prices of goods and services in an economy over a period of time, is also another potential determinant of FDI. Inflation 
defers investment and savings, and because of that it is used to represent economic stability of a country. There have been a few studies manage to expose the negative effect of inflation on FDI. For a vertical type of FDI, inflation brings a huge harm to them, especially when it relates to costs.

Another variable that is employed by this study is the growth rate of GDP. The growth rate of GDP is used to denote future market potential (Bende-Nabende, 2002). Higher growth rates of GDP indicate that the economy of a particular country is expanding. Growing economies are expected to provide more opportunities for the MNEs especially in terms of making profit. This study also addresses the impact of other countries on the Malaysian FDI. Malaysian neighbor countries of Thailand, Indonesia and Philippines are chosen to be included in the study. These three countries are selected because of three main reasons: 1) their location which makes the transportation costs of exporting and importing are not much different from Malaysia, 2) the historical trend of their FDI flows are quite similar to Malaysia, and 3) these countries share similar or nearly similar culture with Malaysia. We shall use the GDP growth rates of the neighbor countries to represent their economic performances which are expected to have a negative impact on the inward flows of Malaysian FDI. In addition, this study also assesses the effect of China's liberalization policy on Malaysian FDI. The impact of the accession of China into the World Trade Organization (WTO) has been assessed by a number of studies (for example, Aw \& Tang, 2010), and they reveal it to be a significant variable. The accession of China into the WTO is used as a dummy variable, and it is expected to have a negative impact of the inflows of Malaysian FDI. In order to test for the robustness of variables as indicated in equation (1), we shall estimate four additional models with different combination of independent variables:

Model 2

$\mathrm{FDI}=\mathrm{F}_{2}(\mathrm{RGDP}, \mathrm{OPEN}, \mathrm{EXR}, \mathrm{GDPG}, \mathrm{CWTO})$

Model 3

FDI $=F_{3}($ RGDP, OPEN,EXR, CWTO)

Model 4

$\mathrm{FDI}=\mathrm{F}_{4}(\mathrm{OPEN}, \mathrm{EXR}, \mathrm{GDPG}, \mathrm{INFL}, \mathrm{CWTO})$

Model 5

$\mathrm{FDI}=\mathrm{F}_{5}(\mathrm{OPEN}, \mathrm{M} 2, \mathrm{GDPG}, \mathrm{CWTO})$

Data: The data are collected from: the World Development Indicators (WDI) and Global Development Finance (GDF) databases, the databases of UNdata, Malaysia Economic Planning Unit (EPU), Malaysia Yearbook of Statistics, ASEAN Secretariat, annual report of Malaysian Industrial Development Authority (MIDA) and annual report of Malaysian Ministry of International Trade and Industry (MITI). This study employs annual data from 1970 to 2009. Data on FDI are based on Malaysian inward flows of FDI obtained from the database of UNCTAD compiled by the World Investment Report (WIR). The data are as of current values in USD, and they are converted into RM using the period average official exchange rate of RM against US Dollar. FDI is used as a dependent variable. Independent variables include real gross domestic product (RGDP), trade openness (OPEN), exchange rate (EXR), financial deepening (M2), inflation (INFL), the growth rate of GDP (GDPG) and the growth rate of GDP for Thailand, Indonesia and Philippines (TGRO=Thailand, INGRO=Indonesia, PGRO=Philippines). The accession of China into the World Trade Organization (WTO) is assessed as a dummy variable.

RGDP is derived by deflating the current GDP data in USD, using the GDP deflator with year 2000 as the base period, and then converted into RM using the period average official exchange rate. The trade openness, OPEN, is the ratio of total exports of goods and services and total imports of goods and services to GDP to represent Malaysia's trade liberalization policy. As for the exchange rate, EXR, it is based on the period average official rate of RM per USD. The depth of Malaysian financial environment is represented by the money supply of M2 monetary aggregate while inflation is represented by the changes in the GDP deflator. Finally, the growth rate of GDP is calculated based on the changes in the current GDP in USD, and all the 
growth rates of selected neighbor countries are the GDP growth rates obtained from the World Bank database. The variables are converted into logarithm except for the inflation and all the growth rates.

Methods of Estimation: Since this study focuses on time series data for the sample period of 1970 to 2009, the first stage is to test the stationarity of all variables to avoid having spurious or nonsense regressions. To assess the stationarity of each variable, each variable is exposed to unit root tests of Augmented Dickey-Fuller (ADF) and Phillips-Perron (PP). After testing for the unit root, this study proceeds with the cointegration estimation techniques of bounds test (Pesaran et al., 2001). Finally, the vector error correction model (VECM) is estimated to determine the dynamic behavior of the FDI. This study highlights five different robust models with different combination of variables with FDI as the dependent variable. However, for the purpose of discussing the estimation technique, only Model 1 is highlighted. Based on Model 1, the conditional VECM is specified as follows:

$$
\begin{aligned}
\triangle \text { LOGFDI }_{t}=c_{0}+ & \delta_{1} \text { LOGFDI }_{t-1}+\delta_{2} \text { LOGRGDP }_{t-1}+\delta_{3} \text { LOGOPEN }_{t-1}+\delta_{4} \text { LOGEXR }_{t-1}+\delta_{5} \text { TGRO }_{t-1} \\
& +\delta_{6} \text { INGRO }_{t-1}+\delta_{7} \text { PGRO }_{t-1} \\
& +\sum_{i=1}^{p} \varphi_{i} \Delta \text { LOGFDI }_{t-i}+\sum_{j=1}^{q} \omega_{j} \Delta L O G R G D P_{t-j} \\
& +\sum_{m=1}^{q} \gamma_{m} \Delta \text { LOGOPEN }_{t-m}+\sum_{n=1}^{q} \tau_{n} \Delta L O G E X R_{t-n}+\sum_{r=1}^{q} \vartheta_{r} \Delta \text { TGRO }_{t-r}+\sum_{s=1}^{q} \varpi_{s} \Delta I N G R O_{t-s} \\
& +\sum_{v=1}^{q} \theta_{v} \Delta \text { PGRO }_{t-v}+\psi D_{t}+\varepsilon_{t}
\end{aligned}
$$

The first step of bounds testing approach is to estimate equations (2) by OLS in order to determine the existence of a long run relationship among the variables by conducting an F-test for the joint significance of the coefficients of the lagged levels of the variables as shown below:

$\mathrm{H}_{0}: \delta_{1}=\delta_{2}=\delta_{3}=\delta_{4}=\delta_{5}=\delta_{6}=\delta_{7}=0$

$\mathrm{H}_{1}: \delta_{1} \neq \delta_{2} \neq \delta_{3} \neq \delta_{4} \neq \delta_{5} \neq \delta_{6} \neq \delta_{7} \neq 0$

The null hypothesis indicates no long run relationship. In determining rejection or acceptance of the null hypothesis, the F-statistic will be compared to the critical value. Since this study employs a small number of observations, the critical values are referred from the tables provided by Narayan (2005). If the F-statistic is greater than the upper critical value of $I(1)$, the null hypothesis of no cointegration is rejected. If it falls below the lower critical value of $I(0)$, the null hypothesis of no cointegration cannot be rejected. If the F-statistic is between the lower and upper bounds, the result is inconclusive. Once the cointegration of the variables for each model is found, the conditional ARDL (p, q1, q2, q3, q4, q5, q6 - depending on the model) long run model for $\mathrm{FDI}_{\mathrm{t}}$ can be estimated, and this would involve selecting the orders of the ARDL using Schwarz Bayesian criteria (SBC). Equation (3) below represents conditional ARDL long run estimations of Model 1:

$$
\begin{aligned}
\operatorname{LOGFDI}_{t}=c_{0}+ & \sum_{i=1}^{p} \delta_{1} \text { LOGFDI }_{t-i}+\sum_{i=0}^{q 1} \delta_{2} \text { LOGRGDP }_{t-i}+\sum_{i=0}^{q 2} \delta_{3} \text { LOGOPEN }_{t-i}+\sum_{i=0}^{q 3} \delta_{4} \text { LOGEXR }_{t-i} \\
& +\sum_{i=0}^{q 4} \delta_{5} \text { TGRO }_{t-i}+\sum_{i=0}^{q 5} \delta_{6} \text { INGRO }_{t-i}+\sum_{i=0}^{q 6} \delta_{7} \text { PGRO }_{t-i}+\psi D_{t}+\varepsilon_{t}
\end{aligned}
$$

Finally, short run dynamic parameters of Model 1 are estimated by estimating an error correction model in (4) associated with the long run estimates. Coefficients of $\varphi, \omega, \gamma, \tau, \vartheta, \varpi$ and $\theta$ in equation (4) are the short run dynamic coefficients of the models' convergence to equilibrium and $\xi$ represents the speed of adjustment. 


$$
\begin{aligned}
\Delta \text { LOGFDI }_{t}=\mu & \\
& +\sum_{i=1}^{p} \varphi_{i} \Delta \text { LOGFDI }_{t-i}+\sum_{j=0}^{q} \omega_{j} \Delta L O G R G D P_{t-j} \\
& +\sum_{m=0}^{q} \gamma_{m} \Delta \text { LOGOPEN }_{t-m} \\
& +\sum_{n=0}^{q} \tau_{n} \Delta L O G E X R_{t-n}+\sum_{r=0}^{q} \vartheta_{r} \Delta T G R O_{t-r}+\sum_{s=0}^{q} \varpi_{s} \Delta I N G R O_{t-s}+\sum_{v=0}^{q} \theta_{v} \Delta \text { PGRO }_{t-v}+\xi \operatorname{ecm}_{t-1} \\
& +\varepsilon_{t}
\end{aligned}
$$

Unit Root Tests Results: Results of the ADF and PP tests (refer to Table 1 and Table 2) verify the use of bounds test in which the dependent variable, the LOGFDI, is $I(1)$ and all other variables are either $I(0)$ or $I(1)$. None of the variables fall under $I(2)$.

Table 1: Unit Root Test Results based on Augmented Dickey Fuller (ADF)

\begin{tabular}{lllll}
\hline Variables & Intercept Only & & \multicolumn{2}{l}{ Trend and Intercept } \\
& Level & First Difference & Level & First Difference \\
\hline LOGFDI & -2.1440 & $-7.1511^{* *}$ & -2.8425 & $-7.2551^{* *}$ \\
LOGRGDP & -1.8303 & $-5.0371^{* *}$ & -1.2315 & $-5.4185^{* *}$ \\
LOGOPEN & -1.3306 & $-4.6647^{* *}$ & -0.5222 & $-4.8791^{* *}$ \\
LOGEXR & -0.8880 & $-4.8512^{* *}$ & -3.3270 & $-4.7422^{* *}$ \\
LOGM2 & -1.1686 & $-7.4054^{* *}$ & -3.4169 & $-7.5800^{* *}$ \\
INFL & $-6.0377^{* *}$ & $-7.7539^{* *}$ & $-6.1024^{* *}$ & $-7.7243^{* *}$ \\
GDPG & $-4.8556^{* *}$ & $-7.7562^{* *}$ & $-5.5089^{* *}$ & $-7.6504^{* *}$ \\
TGRO & $-3.1676^{*}$ & $-6.3431^{* *}$ & -3.4223 & $-6.3072^{* *}$ \\
INGRO & $-4.3315^{* *}$ & $-6.9753^{* *}$ & $-4.6341^{* *}$ & $-6.8763^{* *}$ \\
PGRO & $-3.3354^{*}$ & $-5.9545^{* *}$ & -3.3173 & $-5.8582^{* *}$ \\
\hline
\end{tabular}

Notes: ${ }^{*}$ and ${ }^{* *}$ indicate $5 \%$ and $1 \%$ significance levels

Table 2: Unit Root Test Results based on Phillips-Perron (PP)

\begin{tabular}{lllll}
\hline Variables & Intercept Only & & \multicolumn{2}{l}{ Trend and Intercept } \\
& Level & First Difference & Level & First Difference \\
\hline LOGFDI & -2.0989 & $-7.1541^{* *}$ & -2.8425 & $-7.2828^{* *}$ \\
LOGRGDP & -1.8303 & $-5.0500^{* *}$ & -1.3125 & $-5.4185^{* *}$ \\
LOGOPEN & -1.3253 & $-4.5495^{* *}$ & -0.6357 & $-4.7588^{* *}$ \\
LOGEXR & -1.0561 & $-4.5165^{* *}$ & -2.6462 & $-4.5912^{* *}$ \\
LOGM2 & -1.3514 & $-7.4054^{* *}$ & -3.3512 & $-7.5194^{* *}$ \\
INFL & $-6.0299^{* *}$ & $-14.9897^{* *}$ & $-6.0939^{* *}$ & $-12.7946^{* *}$ \\
GDPG & $-4.2260^{* *}$ & $-11.9863^{* *}$ & $-4.4477^{* *}$ & $-13.9593^{* *}$ \\
TGRO & $-3.1676^{*}$ & $-9.6255^{* *}$ & -3.4223 & $-10.7716^{* *}$ \\
INGRO & $-4.3472^{* *}$ & $-17.3123^{* *}$ & $-4.6587^{* *}$ & $-16.9799^{* *}$ \\
PGRO & $-3.3796^{*}$ & $-7.4136^{* *}$ & -3.3661 & $-7.1616^{* *}$ \\
\hline
\end{tabular}

Notes: ${ }^{*}$ and ${ }^{* *}$ indicate $5 \%$ and $1 \%$ significance levels

\section{Results and Discussion}

This section highlights results and discussions of the main objective of this study: examining determinants of foreign direct investment (FDI). As mentioned earlier, determinants of FDI are examined using the bound test approach. The following topics emphasize the results and discuss each result pertinent to the mentioned objective. 
Descriptive Statistics: Table 3 and Table 4 summarize the descriptive and correlation information of each variable. Table 3 shows mean, median, maximum and minimum values of the variables. The values of skewness given in Table 3 indicate that most of the variables have long left tails except for the LOGEXR and INFL which have long right tails. As for the kurtosis, only the INFL and all four growth rates of GDP exceed the normal distribution of three where their distribution is peaked relative to the normal, while the rests are flat relative to the normal. The Jarque-Bera probabilities indicate that the growth rates of GDP for all four countries are not normally distributed at 1 percent significance level. Table 4 shows correlation matrices of the underlying variables. LOGFDI has positive correlations with LOGRGDP, LOGOPEN, LOGEXR, LOGM2 and INFL, while negative correlations with GDPG, TGRO, INGRO and PGRO. Even though some of the correlation coefficients are high, in excess of 0.8 such as the correlations between LOGFDI and LOGRGDP, LOGFDI and LOGOPEN, and LOGFDI and LOGM2, which may indicate the existence of multicollinearity, its existence may not bias the results and make them inefficient.

Bounds Test Estimation Results: Based on the endogenous variables of FDI, RGDP, OPEN, EXR, M2, INFL, GDPG, TGRO, INGRO and PGRO with the sample period of 1970 to 2009, a VAR lag order selection criteria of Likelihood Ratio (LR), Final Prediction Error (FPE), Akaike Information Criterion (AIC), Schwarz Information Criterion (SIC) and Hannan-Quinn (HQ) information criterion conclusively suggest a maximum lag of 2.Based on equation (2), Table 5 reports cointegration test results of the bounds test approach for models of 1-5. Given that the FDI is the dependent variable for models 1-5, results in Table 5 indicate that the calculated Fstatistics for Model $1=6.8661$ is greater than the upper bound critical value of 5.686 at the one percent significance level indicating that the underlying variables of Model 1 are cointegrated. For Model 2, Model 4 and Model 5, their F-statistics of 4.9046, 5.8575 and 5.8123 respectively are above their upper bound critical values of 4.443 and 4.630 at the 5 percent significance level. These imply the existence of cointegration relationships among the underlying variables for each model. The F-statistics for Model 3 is 4.4305, and it is above the upper bound critical value of 3.898 at the 10 percent significance level.

Table 3: Descriptive Statistics

\begin{tabular}{|c|c|c|c|c|c|c|c|c|c|c|}
\hline & LOGFDI & LOGRGDP & LOGOPEN & LOGEXR & LOGM2 & INFL & GDPG & TGRO & INGRO & PGRO \\
\hline Mean & 9.574262 & 11.24383 & 0.129464 & 0.452784 & 10.37739 & 0.040510 & 0.109010 & 0.059750 & 0.060250 & 0.037500 \\
\hline Median & 9.584281 & 11.23614 & 0.151472 & 0.418553 & 10.35590 & 0.038145 & 0.125498 & 0.060000 & 0.065000 & 0.045000 \\
\hline Maximum & 10.46330 & 11.72309 & 0.343225 & 0.593771 & 11.30300 & 0.178576 & 0.519416 & 0.130000 & 0.100000 & 0.090000 \\
\hline Minimum & 8.459022 & 10.66984 & -0.159526 & 0.337834 & 9.308000 & -0.086378 & -0.279464 & -0.110000 & -0.130000 & -0.070000 \\
\hline Std. Dev. & 0.583364 & 0.324347 & 0.160687 & 0.083605 & 0.571830 & 0.050680 & 0.128206 & 0.042395 & 0.037244 & 0.033417 \\
\hline Skewness & -0.298178 & -0.135391 & -0.185471 & 0.522221 & -0.116156 & 0.092981 & -0.160291 & -1.597730 & -3.470069 & -1.624756 \\
\hline Kurtosis & 1.916357 & 1.758522 & 1.604784 & 1.761354 & 1.910746 & 4.061362 & 5.911740 & 7.851218 & 18.21309 & 6.317777 \\
\hline Jarque-Bera & 2.549871 & 2.690983 & 3.473709 & 4.375169 & 2.067404 & 1.935117 & 14.30167 & 56.24213 & 466.0061 & 35.94496 \\
\hline Probability & 0.279449 & 0.260412 & 0.176073 & 0.112187 & 0.355688 & 0.380010 & 0.000784 & 0.000000 & 0.000000 & 0.000000 \\
\hline
\end{tabular}

After proving the existence of long-run cointegration relationships between the underlying variables for models 1-5, long run coefficients are then estimated using the ARDL approach. Table 6 reports the long run estimates by normalizing on FDI. Using the Schwarz Bayesian Criterion (SBC), a maximum of lag 2 is adopted for all models given the small sample size and the use of annual data (Narayan, 2005; Narayan \& Siyabi, 2005). Results in Table 6 indicate that RGDP is not a significant variable in determining the inward flows of FDI for Malaysia. On the other hand, OPEN is found to be the most robust variable for the determinants of FDI. All five models that incorporate OPEN as one of their independent variables reveal OPEN to be a positive and significant variable at one and 5 percent levels. Results in general indicate that a one percent increase in OPEN leads to more that 4 percent increase in the inward flows of FDI. The insignificant of RGDP together with the significant of OPEN indirectly reflect the motive of FDI for Malaysia. Results of the two variables provide an indication that FDIs in Malaysia are focusing more on the export oriented strategy rather than trying to exploit the host country's market. 
Table 4: Correlation Matrices

\begin{tabular}{lcccccccccc}
\hline & LOGFDI & LOGRGDP & LOGOPEN & LOGEXR & LOGM2 & INFL & GDPG & TGRO & INGRO & PGRO \\
\hline LOGFDI & 1.000000 & & & & & & & & & \\
LOGRGDP & 0.907537 & 1.000000 & & & & & & & & \\
LOGOPEN & 0.922094 & 0.963866 & 1.000000 & & & & & & & \\
LOGEXR & 0.490887 & 0.683465 & 0.688659 & 1.000000 & & & & & & \\
LOGFIN & 0.902064 & 0.997712 & 0.951924 & 0.671627 & 1.000000 & & & & & \\
INFL & 0.032647 & -0.109779 & -0.070161 & -0.152477 & -0.112936 & 1.000000 & & & & \\
GDPG & -0.099990 & -0.236163 & -0.240008 & -0.306133 & -0.221922 & 0.684728 & 1.000000 & & \\
TGRO & -0.242420 & -0.358311 & -0.340267 & -0.437428 & -0.355938 & 0.104847 & 0.565227 & 1.000000 & \\
INGRO & -0.233738 & -0.326239 & -0.370863 & -0.480122 & -0.309941 & 0.068734 & 0.629723 & 0.742164 & 1.000000 \\
PGRO & -0.077715 & -0.095982 & -0.069336 & 0.039243 & -0.083546 & 0.338912 & 0.472757 & 0.289132 & 0.293069 & 1.000000 \\
\hline
\end{tabular}

Table 5: Cointegration Test Results

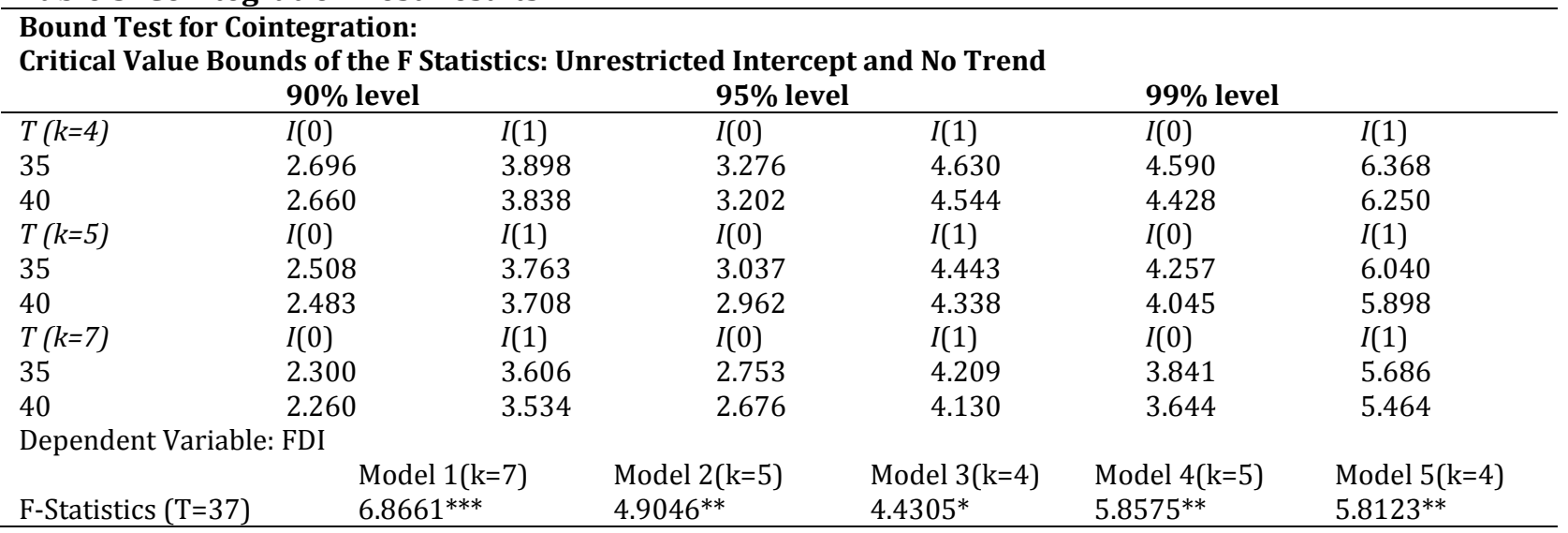

Notes: ${ }^{* *},{ }^{* *}$ and ${ }^{*}$ denote $1 \%, 5 \%$ and $10 \%$ significance levels respectively.

Unlike OPEN, even though EXR is found to be a significant variable, the sign is not as expected. Results indicate that a depreciation of RM by 1 percent is found to reduce the inflows of FDI by roughly 1.7 to 2 percent. Another variable that is found to be significant occasionally in the long run is the growth rate of GDP. Model 5 indicates that the growth rate of GDP is positive and significant at 10 percent level. The growth rate of GDP for selected neighbor countries is not significant. Interestingly, even though the growth rates of the neighbor countries are not significant, their negative signs may suggest that these countries could potentially become competitors for Malaysia in terms of attracting FDI. Conversely, the dummy variable of CWTO shows a positive coefficient in the long run, and it is significant at 10 percent level. As indicated by Aw and Tang (2010), the positive impact in the long run is due to the increase in opportunities to have access into the China's market. Finally, inflation rates (INFL) and the M2 are found to be insignificant. The insignificant of inflation may be due to the low inflation experienced by Malaysia. While for the financial market, it can be assumed that foreign investors do not heavily rely on our domestic financial market as their main source of capital since they can also get the capital from their own home countries. 
Table 6: Estimated Long Run Coefficients using the ARDL Approach Selected Based on Schwarz Bayesian Criterion (SBC)

\begin{tabular}{|c|c|c|c|c|c|}
\hline Dependen & $\begin{array}{l}\text { lable is LOGFDI } \\
\text { Model 1 } \\
(1,1,0,0,0,0,0,1)\end{array}$ & $\begin{array}{l}\text { Model 2 } \\
(\mathbf{1 , 0 , 0 , 0 , 0 , 1 )}\end{array}$ & $\begin{array}{l}\text { Model 3 } \\
(\mathbf{1}, \mathbf{1}, \mathbf{0}, \mathbf{0}, \mathbf{1})\end{array}$ & $\begin{array}{l}\text { Model 4 } \\
(\mathbf{1}, \mathbf{0}, \mathbf{0}, \mathbf{0}, \mathbf{0}, \mathbf{1})\end{array}$ & $\begin{array}{l}\text { Model 5 } \\
(\mathbf{1 , 0 , 0 , 0 , 2 )}\end{array}$ \\
\hline LOGRGDP & $\begin{array}{l}-1.1359 \\
(0.87188) \\
{[-1.3028]}\end{array}$ & $\begin{array}{l}-0.90677 \\
(0.82363) \\
{[-1.1009]}\end{array}$ & $\begin{array}{l}-1.0185 \\
(0.85006) \\
{[-1.1981]}\end{array}$ & - & - \\
\hline LOGOPEN & $\begin{array}{l}5.6911 \\
(1.5295) \\
{[3.7209]^{* * *}}\end{array}$ & $\begin{array}{l}5.6074 \\
(1.4879) \\
{[3.7687]^{* * *}}\end{array}$ & $\begin{array}{l}5.6159 \\
(1.5155) \\
{[3.7057]^{* * *}}\end{array}$ & $\begin{array}{l}4.0260 \\
(0.32352) \\
{[12.4444]^{* * *}}\end{array}$ & $\begin{array}{l}6.3232 \\
(2.4910) \\
{[2.5384]^{* *}}\end{array}$ \\
\hline LOGEXR & $\begin{array}{l}-1.7275 \\
(0.95616) \\
{[-1.8067]^{*}}\end{array}$ & $\begin{array}{l}-2.0226 \\
(0.82590) \\
{[-2.4490]^{* *}}\end{array}$ & $\begin{array}{l}-1.7747 \\
(0.85742) \\
{[-2.0698]^{* *}}\end{array}$ & $\begin{array}{l}-1.7888 \\
(0.74140) \\
{[-2.4128]^{* *}}\end{array}$ & - \\
\hline LOGM2 & - & - & - & - & $\begin{array}{l}-0.91311 \\
(0.83882) \\
{[-1.0886]}\end{array}$ \\
\hline TGRO & $\begin{array}{l}-0.35111 \\
(1.3738) \\
{[-0.25558]}\end{array}$ & - & - & - & - \\
\hline INGRO & $\begin{array}{l}-0.29654 \\
(1.8590) \\
{[-0.15951]}\end{array}$ & - & - & - & - \\
\hline PGRO & $\begin{array}{l}-1.7205 \\
(1.2615) \\
{[-1.3639]}\end{array}$ & - & - & - & - \\
\hline GDPG & - & $\begin{array}{l}0.53107 \\
(0.32711) \\
{[1.6235]}\end{array}$ & - & $\begin{array}{l}0.48265 \\
(0.37909) \\
{[1.2732]}\end{array}$ & $\begin{array}{l}1.3078 \\
(0.69068) \\
{[1.8935]^{*}}\end{array}$ \\
\hline INFL & - & - & - & $\begin{array}{l}0.12975 \\
(0.87758) \\
{[0.14785]}\end{array}$ & - \\
\hline CWTO & $\begin{array}{l}0.43596 \\
(0.22479) \\
{[1.9394]^{*}}\end{array}$ & $\begin{array}{l}0.30796 \\
(0.19925) \\
{[1.5456]}\end{array}$ & $\begin{array}{l}0.36723 \\
(0.20411) \\
{[1.7991]^{*}}\end{array}$ & $\begin{array}{l}0.13633 \\
(0.11546) \\
{[1.1807]}\end{array}$ & $\begin{array}{l}0.14192 \\
(0.29452) \\
{[0.48188]}\end{array}$ \\
\hline INPT & $\begin{array}{l}22.2456 \\
(9.6299) \\
{[2.3100]^{* *}}\end{array}$ & $\begin{array}{l}19.8895 \\
(9.1569) \\
{[2.1721]^{* *}}\end{array}$ & $\begin{array}{l}20.9351 \\
(9.4174) \\
{[2.2230]^{* *}}\end{array}$ & $\begin{array}{l}9.8150 \\
(0.30074) \\
{[32.6363]^{* * *}}\end{array}$ & $\begin{array}{l}18.1574 \\
(8.3416) \\
{[2.1767]^{* *}}\end{array}$ \\
\hline
\end{tabular}

Notes: ${ }^{* *},{ }^{* *}$ and ${ }^{*}$ denote $1 \%, 5 \%$ and $10 \%$ significance levels respectively. Standard errors and t-statistics are in parentheses and brackets respectively.

In addition to the long run estimations, we also evaluate short run estimates as given in Table 7. Despite the insignificant of RGDP in the long run, some of the short run models suggest it to be positive and significant at 10 percent level. Similar to the long run estimates, OPEN is positive and significant at one percent level in all models tested. These short run results further strengthen the robustness of OPEN as a determining variable for the inward flows of FDI for Malaysia. Correspondingly, EXR is also found to be negative and significant in influencing the inward flows of FDI in the short run at 5 percent and 10 percent levels depending on the model. A one percent decrease in the value of the RM is reflected in a drop in the inward flows of FDI by 1.1 
to 1.3 percent. The Malaysian growth rate of GDP is also found to be positive and significant in the short run. Based on Model 5, a one percent increase in the growth rate of GDP is reflected in a 0.5 percent increase in the inward flows of FDI. As for the growth rates of GDP of Thailand, Indonesia and Philippines, even though their coefficients are not significant, they persistently show negative results. Opposite to the long run coefficients, CWTO is found to be negative and significant in affecting FDI at 1 percent level in all 5 models tested. Similar to the long run results, M2 and INFL are not significant in the short run.

Table 7: Error Correction Representation for the Selected ARDL Model selected based on Schwarz Bayesian Criterion (SBC)

\begin{tabular}{|c|c|c|c|c|c|}
\hline Dependent Va & $\begin{array}{l}\text { able is dLOGFDI } \\
\text { Model } 1 \\
(1,1,0,0,0,0,0,1)\end{array}$ & $\begin{array}{l}\text { Model 2 } \\
(\mathbf{1 , 0 , 0 , 0 , 0 , 1 )}\end{array}$ & $\begin{array}{l}\text { Model 3 } \\
(\mathbf{1}, \mathbf{1}, \mathbf{0 , 0 , 1 )}\end{array}$ & $\begin{array}{l}\text { Model 4 } \\
(1,0,0,0,0,1)\end{array}$ & $\begin{array}{l}\text { Model } 5 \\
(1,0,0,0,2)\end{array}$ \\
\hline dLOGRGDP & $\begin{array}{l}.4204 \\
(2.4691) \\
{[1.7903]^{*}}\end{array}$ & $\begin{array}{l}-0.59743 \\
(0.47533) \\
{[-1.2569]}\end{array}$ & $\begin{array}{l}2.8374 \\
(1.6177) \\
{[1.7540]^{*}}\end{array}$ & - & - \\
\hline dLOGOPEN & $\begin{array}{l}3.6899 \\
(0.74022) \\
\quad[4.9849]^{* * *}\end{array}$ & $\begin{array}{l}3.6944 \\
(0.71413) \\
\quad[5.1733]^{* * *}\end{array}$ & $\begin{array}{l}3.5254 \\
(0.70397) \\
\quad[5.0078]^{\text {*** }}\end{array}$ & $\begin{array}{l}2.9816 \\
(0.44929) \\
\quad[6.6362]^{* * *}\end{array}$ & $\begin{array}{l}2.6324 \\
(0.61252) \\
{[4.2976]^{* * *}}\end{array}$ \\
\hline dLOGEXR & $\begin{array}{l}-1.1201 \\
(0.64999) \\
{[-1.7232]^{*}}\end{array}$ & $\begin{array}{l}-1.3326 \\
(0.56668) \\
{[-2.3516]^{* *}}\end{array}$ & $\begin{array}{l}-1.1141 \\
(0.57178) \\
{[-1.9484]^{*}}\end{array}$ & $\begin{array}{l}-1.3248 \\
(0.58935) \\
{[-2.2479]^{* *}}\end{array}$ & - \\
\hline dLOGM2 & - & - & - & - & $\begin{array}{l}-0.38013 \\
(0.26098) \\
{[-1.4566]}\end{array}$ \\
\hline dTGRO & $\begin{array}{l}-0.22765 \\
(0.90170) \\
{[-0.25247]}\end{array}$ & - & - & - & - \\
\hline dINGRO & $\begin{array}{l}-0.19227 \\
(1.2001) \\
{[-0.16020]}\end{array}$ & - & - & - & - \\
\hline dPGRO & $\begin{array}{l}-1.1155 \\
(0.80562) \\
{[-1.3847]}\end{array}$ & - & - & - & - \\
\hline dGDPG & - & $\begin{array}{l}0.34990 \\
(0.19605) \\
{[1.7847]^{*}}\end{array}$ & - & $\begin{array}{l}0.35745 \\
(0.26834) \\
{[1.3320]}\end{array}$ & $\begin{array}{l}0.54443 \\
(0.19362) \\
{[2.8118]^{* * *}}\end{array}$ \\
\hline dINFL & - & - & - & $\begin{array}{l}0.096092 \\
(0.64884) \\
{[0.14810]}\end{array}$ & - \\
\hline dCWTO & $\begin{array}{l}-0.63587 \\
(0.16779) \\
{[-3.7896]^{* * *}}\end{array}$ & $\begin{array}{l}-0.70507 \\
(0.15646) \\
\quad[-4.5064]^{* * *}\end{array}$ & $\begin{array}{l}-0.66696 \\
(0.15208) \\
\quad[-4.3857]^{* * *}\end{array}$ & $\begin{array}{l}-0.72647 \\
(0.16244) \\
{[-4.4724]^{* * *}}\end{array}$ & $\begin{array}{l}-0.82457 \\
(0.15005) \\
{[-5.4953]^{* * *}}\end{array}$ \\
\hline dCWT01 & - & - & - & - & $\begin{array}{l}0.35167 \\
(0.18639) \\
{[1.8867]^{*}}\end{array}$ \\
\hline dINPT & $\begin{array}{l}14.4234 \\
(4.7859) \\
{[3.0138]^{* * *}}\end{array}$ & $\begin{array}{l}13.1043 \\
(4.7508) \\
\quad[2.7583]^{* * *}\end{array}$ & $\begin{array}{l}13.1421 \\
(4.5716) \\
{[2.8747]^{* * *}}\end{array}$ & $\begin{array}{l}7.2688 \\
(1.0521) \\
\quad[6.9091]^{* * *}\end{array}$ & $\begin{array}{l}7.5590 \\
(2.1700) \\
{[3.4834]^{* * *}}\end{array}$ \\
\hline ecm $(-1)$ & $\begin{array}{l}-0.64837 \\
(0.12488) \\
{[-5.1921]^{* * *}}\end{array}$ & $\begin{array}{l}-0.65885 \\
(0.11946) \\
{[-5.5152]^{* * *}}\end{array}$ & $\begin{array}{l}-0.62775 \\
(0.11792) \\
{[-5.3233]^{* * *}}\end{array}$ & $\begin{array}{l}-0.74058 \\
(0.10246) \\
{[-7.2279]^{* * *}}\end{array}$ & $\begin{array}{l}-0.41630 \\
(0.14044) \\
{[-2.9644]^{* * *}}\end{array}$ \\
\hline R-Squared & 0.82118 & 0.79555 & 0.80747 & 0.78494 & 0.78596 \\
\hline R-Bar-Squared & 0.75495 & 0.74784 & 0.76255 & 0.73476 & 0.73602 \\
\hline F-stat & $15.4985^{* * *}$ & $19.4558^{* * *}$ & $25.1647^{* * *}$ & $18.2494^{* * *}$ & $18.3604^{* * *}$ \\
\hline
\end{tabular}

Notes: $^{* * *},{ }^{* *}$ and ${ }^{*}$ denote $1 \%, 5 \%$ and $10 \%$ significance levels respectively. Standard errors and t-statistics are in parentheses and brackets respectively. 
Table 7 shows that the error correction terms are highly significant at one percent level for all 5 models with the correct negative sign, which ensure that the long run equilibrium can be attained. Depending on the model, the error correction terms indicate that roughly 40 to 70 percent of the previous year's deviation from the long run equilibrium is restored in the current year. In addition, the adjusted R-squared of the error correction representation of all 5 models is more than 70 percent, indicating that more than 70 percent of the variation in the inward flows of Malaysian FDI is explained by independent variables in each model. Table 8 summarizes diagnostic tests of serial correlation, functional form, normality and heteroscedasticity for all five ARDL models based on LM version. All 5 models satisfy serial correlation, functional form and normality assumptions, while Model 1 and Model 3 fail heteroscedasticity test at 5 percent significance level. Nevertheless, according to Shrestha and Chowdhury (2005), since ARDL models can consist of a combination of $I(0)$ and $I(1)$ variable, "it is natural to detect heteroscedasticity."

Table 8: Diagnostic Tests (LM Version) of the Autoregressive Distributed Lag Estimates (ARDL)

\begin{tabular}{llllll}
\hline & Model 1 & Model 2 & Model 3 & Model 4 & Model 5 \\
\hline Serial Correlation & 0.065616 & 0.042109 & 0.040755 & 0.59848 & 0.21262 \\
& $(0.798)^{\mathrm{a}}$ & $(0.837)$ & $(0.840)$ & $(0.439)$ & $(0.645)$ \\
Functional Form & {$[1]^{\mathrm{b}}$} & {$[1]$} & {$[1]$} & {$[1]$} & {$[1]$} \\
& 0.13629 & 0.37189 & 0.60810 & 0.058450 & 2.5627 \\
& $(0.712)$ & $(0.542)$ & $(0.436)$ & $(0.809)$ & $(0.109)$ \\
Normality & {$[1]$} & {$[1]$} & {$[1]$} & {$[1]$} & {$[1]$} \\
& 1.6442 & 2.2844 & 1.3651 & 2.6101 & 2.3933 \\
Heteroscedasticity & $(0.440)$ & $(0.319)$ & $(0.505)$ & $(0.271)$ & $(0.302)$ \\
& {$[2]$} & {$[2]$} & {$[2]$} & {$[2]$} & {$[2]$} \\
& $(0.1392$ & 2.6843 & 3.8802 & 0.90223 & 1.2180 \\
& {$[1]$} & $(0.101)$ & $(0.049)^{* *}$ & $(0.342)$ & $(0.270)$ \\
\hline
\end{tabular}

Notes: a,b Numbers in parentheses and brackets are probabilities and number of lags respectively.

\section{Conclusion}

The main objective of this study is to identify determinants of the inward flows of FDI for Malaysia by employing the bounds testing (ARDL) approach to cointegration. Results show the existence of long run cointegration relationships among the underlying variables in all 5 models. Of all the variables, OPEN and EXR show consistent results in the short run as well as in the long run. OPEN has the highest significance level with a positive sign, and it can be considered as the most robust variable due to its consistency in maintaining its significance at one percent level both in the short run as well as in the long run and also in all models being tested. These results are consistent with the results of Ang (2008), Yol and Teng (2009) and Aw and Tang (2010). Since OPEN which represents the liberalization of the Malaysian economy could induce the inflows of FDI, policy makers should initiate policies that can enhance the trade openness. Since Malaysia has established Free Trade Zones and hi-tech parks for the convenience of investors to operate, the Government can always get feedback from the tenants of those FTZs and parks regarding the facilities provided and their expectations.

On the other hand, even though the EXR is found to be significant, its sign is not as expected. It is found to be negative and significant where the depreciation of RM would decrease the inward flows of Malaysian FDI in the long run as well as in the short run. These results contradict the results of some past studies (for example Almsafir et al., 2011; Yol \& Teng, 2009) which indicate a positive relationship between the exchange rate and FDI. The negative relationship between EXR and FDI indicates that foreign direct investors prefer RM to appreciate in value. When RM appreciates in value, the value of assets that they are holding, particularly measured in RM, would also increase. GDP which represents the market size is significant in the short run but not in the long run which contradict the results of Ang (2008) and Ismail and Yussof (2003)but support the findings by Aw and Tang (2010). The insignificant of the GDP in the long run indicates that investors are not trying to exploit the local market. The significant of trade openness explains why the GDP is relatively not 
significant in the long run. Nevertheless, since GDP is one of important economic indicators of any country, in the short run, it will be used by potential investors to assist them in their decision of investing abroad. Based on the results of long run and short run estimations, we can see that foreign investors are more concern on the short run economic growth of the host country. Finally, the accession of China into the WTO has been found to be negative and significant in affecting the inward flows of Malaysian FDI in the short run. However, in the long run, the results are positive and significant. These results strengthen the results by Aw and Tang (2010) and Cuyvers et al. (2008) where even though the accession of China in the WTO creates a shock in the short run to Malaysia, later, China's action has resulted in a positive spillover effect in the inward flows of FDI for Malaysia.

\section{References}

Almsafir, M. K., Latif, N. W. A. \& Bekhet, H. A. (2011). Analyzing the Green Field Investment in Malaysia from 1970 to 2009: a Bound Testing Approach. Australian Journal of Basic and Applied Sciences, 5(3), 561570.

Ang, J. B. (2008). Determinants of Foreign Direct Investment in Malaysia. Journal of Policy Modeling, 30, 185189.

Asiedu, E. (2002). On the Determinants of Foreign Direct Investment to Developing Countries: Is Africa Different? World Development, 30(1), 107-119.

Aw, T. Y. \& Tang, T.-C. (2010). The Determinants of Inward Foreign Direct Investment: The Case of Malaysia. International Journal of Business and Society, 11(1), 59-76.

Bende-Nabende, A. (2002). Foreign Direct Investment Determinants in Sub-Sahara Africa: A Co-integration Analysis. Economics Bulletin, 6(4), 1-19.

Bevan, A. A. \& Estrin, S. (2004). The Determinants of Foreign Direct Investment into European Transition Economies. Journal of Comparative Economics, 32, 775-787.

Bjorvatn, K., Kind, H. J. \& Nordas, H. K. (2001). The Role of FDI in Economic Development. SNF Working Paper $62 / 01$.

Cassidy, J. F. \& Andreosso-0'Callaghan, B. (2006). Spatial Determinants of Japanese FDI in China. Japan and the World Economy, 18, 512-527.

Cuyvers, L., Joseph, P., Soeng, R. \& Bulcke, D. V. D. (2008). Determinants of Foreign Direct Investment in Cambodia: Country-Specific Factor Differentials. University of Antwerp. Research Paper 2008-003. D/2008/1169/003.

Demirhan, E. \& Masca, M. (2008). Determinants of Foreign Direct Investment Flows to Developing Countries: A Cross-Sectional Analysis. Prague Economic Papers, 4, 356-369.

Fedderke, J. W. \& Romm, A. T. (2006). Growth Impact and Determinants of Foreign Direct Investment into South Africa, 1956-2003. Economic Modelling, 23, 738-760.

Gao, T. (2005). Labor Quality and the Location of Foreign Direct Investment: Evidence from China. China Economic Review, 16, 274-292.

Hasan, Z. (2004). Determinants of FDI Flows to Developing Economies: Evidence from Malaysia. In H. S. Kehal (Ed.), Foreign Investment in Developing Countries (pp. 154-170). UK: Palgrave Macmillan.

Ismail, R. \& Yussof, I. (2003). Labor Market Competitiveness and Foreign Direct Investment: The Case of Malaysia, Thailand and the Philippines. Papers in Regional Science, 82, 389-402.

Kang, S. J. \& Lee, H. S. (2007). The Determinants of Location Choice of South Korean FDI in China. Japan and the World Economy, 19, 441-460.

Kiyota, K. \& Urata, S. (2004). Exchange Rate, Exchange Rate Volatility and Foreign Direct investment. The World Economy, 27(10), 1501-1536.

Li, X. \& Liu, X. (2005). Foreign Direct Investment and Economic Growth: An Increasingly Endogenous Relationship. World Development, 33(3), 393-407.

Lim, E. G. (2001). Determinants of, and the Relation Between, Foreign Direct Investment and Growth: A Summary of the Recent Literature. IMF Working Paper, WP/01/175(November).

Moosa, I. A. \& Cardak, B. A. (2006). The Determinants of Foreign Direct Investment: An Extreme Bounds Analysis. Journal of Multinational Financial Management, 16, 199-211. 
Narayan, P. K. (2005). The Saving and Investment Nexus for China: Evidence from Cointegration Tests. Applied Economics, 37, 1979-1990.

Narayan, P. \& Siyabi, S. A. (2005). An Empirical Investigation of the Determinants of Oman's National Savings. Economics Bulletin, 3(51), 1-7.

Noorbakhsh, F., Paloni, A. \& Youssef, A. (2001). Human Capital and FDI Inflows to Developing Countries: New Empirical Evidence. World Development, 29(9), 1593-1610.

Pesaran, M. H., Shin, Y. \& Smith, R. J. (2001). Bounds Testing Approaches to the Analysis of Level Relationships. Journal of Applied Econometrics, 16, 289-326.

Shahrudin, N., Yusof, Z. \& Satar, N. M. (2010). Determinants of Foreign Direct Investment in Malaysia: What Matters Most? International Review of Business Research Papers, 6(6), 235-245.

Solocha, A., Soskin, M. D. \& Kasoff, M. J. (1989). Canadian Investment in Northern New York: Impact of Exchange Rates on Foreign Direct Investment. Growth and Change (Winter), 1-16.

Yol, M. A. \& Teng, N. T. (2009). Estimating the Domestic Determinants of Foreign Direct Investment Flows in Malaysia: Evidence from Cointegration and Error-Correction Model. Jurnal Pengurusan, 28, 3-22. 